\title{
Uma Experiência a nos Inspirar
}

\section{An Experience that inspires us}

\section{Resenha}

CARDOSO, M. Fátima Toledo: interpretar a vida, viver o cinema. São Paulo: LiberArs, 2014, 248p.

Alecsandra Matias de Oliveira ${ }^{1}$

1 Graduação em História pela Faculdade de Filosofia, Letras e Ciências Humanas (1995), mestrado em Ciências da Comunicação pela Universidade de São Paulo (2003) e doutorado em História da Arte pela Escola de Comunicação e Artes da Universidade de São Paulo (2008). Atualmente é especialista em cooperação e extensão universitária do Museu de Arte Contemporânea da Universidade de São Paulo. E-mail: alemaoli@usp.br 


\section{////////////////////////////////////////////////////////}

Uma Experiência a nos Inspirar | Alecsandra Matias de Oliveira

Resumo: Fátima Toledo, reconhecida preparadora de elenco, narra sua trajetória profissional a partir de grandes produções cinematográficas nacionais, como Pixote, Cidade de Deus, Tropa de Elite e Linha de Passe. No centro de suas preocupações está a formação do Método de interpretação que ela vem construindo em três décadas de carreira e mais de trinta e cinco filmes no currículo. Fátima Toledo - interpretar a vida, viver o cinema tem narrativa sensível e instigante sobre o trabalho de interpretação de atores. Nesse sentido, torna-se uma obra relevante para a história do cinema brasileiro.

Palavras-chaves: Fátima Toledo; preparação de elenco; cinema brasileiro.

- Que é isso menino, por a mão para trás e abaixar os olhos pra falar comigo? Eu não sou polícia. Olha direito para mim, vamos. Quem é você, qual o teu nome? (Depoimento de Hector Babenco sobre Fátima Toledo).

"Quem é você"? Esse é o pensamento-chave para a compreensão do livro Fátima Toledo: interpretar a vida, viver o cinema e, principalmente, do Método da preparadora de atores para o cinema Fátima Toledo. Atuante no mercado cinematográfico desde a década de 1980, ela expõe suas memórias, de modo delicado e consciente, em entrevistas, concedidas entre 2005 e 2008, ao historiador Maurício Cardoso, que registrou e editou os depoimentos. De modo cronológico, a trajetória de Fátima é exposta em 19 filmes que contribuíram para a organização do seu Método. Ao revés dos ensinamentos de Stanislavski, no Método, o que é mais significativo é saber "quem é você". O ator não se aproxima do personagem; ele deve vivenciar suas emoções e não seus sentimentos. Nesse exercício, ele deve conhecer a si mesmo. Encarar o Método de frente é mergulhar nas emoções reivindicadas pelas situações exigidas pelo filme.

O livro conta com prefácio assinado por Luis Marra (escritor e amigo de Fátima). A 


\section{/////////////////////////////////////////////////////////////}

Uma Experiência a nos Inspirar | Alecsandra Matias de Oliveira

seguir, os capítulos desfilam pelos filmes nos quais a preparadora atuou de forma ativa, sendo eles: Pixote, a lei do mais fraco (Hector Babenco); Brincando nos Campos do Senhor (Hector Babenco); Medice Man (John McTreirnan); Sábado (Ugo Giorgetti); Boleiros, era uma vez o futebol (Ugo Giorgetti); Dois córregos, verdades submersas no tempo (Carlos Reichenbach); Garotas do ABC, Aurélia Schwarzenega (Carlos Reichenbach); Tainá, uma aventura na Amazônia (Tânia Lamarca e Sergio Bloch); Tainá 2, a aventura continua (Mauro Lima); Desmundo (Alain Fresnot); Central do Brasil (Walter Salles); O mundo em duas voltas (documentário sobre a família Shürmann - David Shürmann); Cidade de Deus (Fernando Meirelles); Cidade Baixa (Sérgio Machado); O céu de Suely (Karim Aïnouz); Mutum (Sandra Kogut); A casa de Alice (Chico Teixeira); Tropa de Elite (José Padilha) e Linha de Passe (Walter Salles e Daniela Thomas).

Organizada com informações técnicas (tais como direção, ano de produção, produtora, elenco e sinopse de cada filme), a publicação torna-se referencial para os adeptos dos estudos do cinema. Os testemunhos de Fátima também possuem uma sistemática interna (das primeiras experiências com o filme, o desafio dos treinamentos e a contribuição dos acontecimentos para a formação do Método). Por fim, a essa estrutura ainda cabem os depoimentos de diretores, atores e não-atores que vivenciaram o Método. Nessa dinâmica, sente-se a mão invisível de Maurício Cardoso - responsável por organizar o material.

A narrativa de Fátima Toledo é fascinante e apaga qualquer imprecisão do projeto gráfico $^{2}$. Suas experiências são envolventes: vive-se com ela cada busca, cada aventura fora e dentro do set. Descobre-se a importância da seleção do elenco, o respeito às determinações dos diretores e, sobretudo, o valor da entrega incondicional do elenco. Pelo olhar de Fátima, percebe-se que os filmes são apostas (ninguém sabe se vai dar certo!). Essa aposta não é bancada somente pelos diretores, roteiristas e atores, mas por

\footnotetext{
$2 \mathrm{O}$ projeto gráfico é bem intencionado, à primeira vista parece sofisticado, porém, deixar a desejar em muitos pontos: a escolha da fonte semi-serifada, com afastamento entre linhas pequeno e recuo menor para acentuar os parágrafos, talvez não seja a ideal, uma vez que exige esforço visual do leitor. A revisão e a padronização da obra também sofrem com deslizes desnecessários, assim como a predileção pelo papel que se ressente de não ser o melhor para a impressão e, especialmente, para suportar anotações que por ventura o leitor queira imprimir ao texto (com a pressão do lápis ou da caneta, o verso da folha é marcado com um "efeito carbono") - o que para um livro de estudo é algo a ser aperfeiçoado. Aqui se registra que o livro poderia ser adotado como suporte metodológico em aulas de graduação e pós-graduação.
} 


\section{/////////////////////////////////////////////////////////}

Uma Experiência a nos Inspirar | Alecsandra Matias de Oliveira

uma equipe de profissionais, entre eles, os preparadores de elenco - dos quais ela é pioneira e referência. Afinal, a demanda por preparadores de atores antes de sua atuação era tida como algo oneroso e dispensável na produção de um filme.

As experiências registradas em Pixote, a lei do mais fraco, em Cidades de Deus, Tropa de Elite e Linha de passe constituem-se como pontos altos do livro. São narrativas cheias de tensão e apreensões. O leitor, mesmo conhecendo o enredo dos filmes, rememora a força e os embates de cada personagem - agora, sob a tutela de Fátima, ele reflete sobre as dificuldades e, acima de tudo, sobre a emoção que estaria presente naquela cena. A relação ator-preparador transforma-se em "passeio de montanha-russa"; a linha entre racional e emocional atenua-se e o leitor vivencia aqueles instantes de preparação para as filmagens de maneira intensa e vibrante.

Através de exercícios de biodança e jogos de dramatização, Fátima preparou expoentes como Marília Pêra, Stênio Garcia, Lázaro Ramos, Alice Braga, Wagner Moura, entre outros autores e não-atores. O Método - colocado no livro quase como um personagem que ganha corpo e alma a cada filme - emergiu de uma trajetória profissional plena de desafios e aprendizados. 'Para o Método não há 'construção de personagem', há construção de situações, por isto, no início da preparação defino o que é preciso trazer dos atores para construir o foco das cenas e inseri-los no universo do filme" (2014, p. 63-64).

À luz dessas considerações, Fátima Toledo: interpretar a vida, viver o cinema pode ser compreendido como o resgate sensível de uma vida profissional intensa, porém, ganha maior dimensão à medida que elucida a história do cinema brasileiro contemporâneo, colocando-se, ainda, como um instrumento para a reflexão sobre métodos e procedimentos adotados nas produções cinematográficas nacionais. De Pixote, a lei do mais fraco a Linha de passe, mais do que desvendar o que é o Método, o livro constrói uma história do cinema nacional recente, tornando-se uma experiência a nos inspirar.

submetido em: 19 jun. 2014 | aprovado em: 21 out. 2014 